\title{
Double blind trial of nicotinamide in recent-onset IDDM (the IMDIAB III study)
}

\author{
P. Pozzilli, N. Visalli, A. Signore, M. G. Baroni, R. Buzzetti, M. G. Cavallo, M. L. Boccuni, D. Fava, C. Gragnoli, \\ D. Andreani, L. Lucentini, M. C. Matteoli, A. Crinò, C. A. Cicconetti, C. Teodonio, F. Paci, R. Amoretti, L. Pisano, \\ M. G. Pennafina, G. Santopadre, G. Marozzi, G. Multari, M. A. Suppa, L. Campea, G. C. De Mattia, M. Cassone \\ Faldetta, G. Marietti, F. Perrone, A. V. Greco, G. Ghirlanda
}

The IMDIAB Study Group, Rome, Italy

Summary Nicotinamide has been recently introduced, in addition to intensive insulin therapy for patients with recent-onset insulin-dependent diabetes mellitus (IDDM) to protect beta cells from endstage destruction. However, available data are conflicting. A double blind trial in 56 newly-diagnosed IDDM patients receiving nicotinamide for 12 months at a dose of $25 \mathrm{mg} / \mathrm{kg}$ body weight or placebo was designed in order to determine whether this treatment could improve the integrated parameters of metabolic control (insulin dose, glycated haemoglobin and C-peptide secretion) in the year after diagnosis. In addition to nicotinamide or placebo, patients received three to four insulin injections daily to optimize blood glucose levels. Patients treated with nicotinamide or placebo received similar doses of insulin during follow-up and 1 year after diagnosis with comparable glycated haemoglobin levels (6.7 $\pm 1.8 \%$ nicotinamide vs $7.1 \pm 0.6 \%$ placebo). Basal and glucagon stimulated C-peptide secretion detectable at diagnosis were similarly preserved in the course of 12 months follow-up both in nicotinamide and placebo treated patients. No adverse effects were observed in patients receiving nicotinamide. When age at diagnosis was taken into account, nicotinamide treated older patients ( $>15$ years of age) showed significantly higher stimulated C-peptide secretion than placebo treated patients $(p<0.02)$. These results suggest that nicotinamide can preserve and improve stimulated beta-cell function only in patients diagnosed after puberty. We conclude that in these patients nicotinamide can be added to insulin at the time of disease diagnosis to maintain and possibly improve residual beta-cell function. However, further studies on patients diagnosed after puberty are needed to confirm whether nicotinamide can be considered an additional tool to insulin in early-onset IDDM. [Diabetologia (1995) 38: 848-852]

Key words Nicotinamide, insulin-dependent diabetes mellitus, C-peptide, insulin therapy.
Nicotinamide (NA) is one of the promising substances currently being considered for secondary prevention of insulin-dependent diabetes mellitus IDDM [1].

Acting at three different levels NA reduces the toxicity of free oxygen radical scavengers produced by lymphocytes and macrophages in the islet cell infiltrate and may improve insulin secretion by increas-

Received: 20 June 1994 and in final revised form: 20 January 1995

Corresponding author: Dr. P. Pozzilli, Endocrinologia (I), II Clinica Medica, Policlinico Umberto I, I-00161 Rome, Italy

Abbreviations: NA, Nicotinamide. ing intracellular NAD and promote beta-cell regeneration [2]. More recently it has been shown that NA is able to prevent the toxic effect of nitric oxide on islets [3] and to abolish the interleukin $1 \mathrm{~b}$ inhibition of islet insulin release [4]. The effect of NA is dose dependent being maximal at $25 \mathrm{mmol} / \mathrm{l}$; a higher dose $(50 \mathrm{mmol} / \mathrm{l})$ stimulates insulin synthesis and increases islet survival in vitro [5].

The first pilot study in recent-onset IDDM, showed that administration of NA at doses of $3 \mathrm{~g}$ daily had a beneficial effect on the clinical remission rate [6]. In our first experience, NA was used successfully to improve metabolic control [7].

Following these initial studies, small trials have been carried out in patients with newly-diagnosed 
IDDM looking at both clinical and partial remission as well as the integrated parameters of metabolic control (basal and stimulated C-peptide secretion, and glycated haemoglobin [8-13]. In these trials NA alone or in combination with other agents, namely cyclosporine, was administered in a variety of doses, ranging from $4 \mathrm{mg} / \mathrm{kg}$ to $45 \mathrm{mg} / \mathrm{kg}$ body weight. Discordant results were obtained; some studies showed a beneficial effect on C-peptide secretion [7, 8, 13], others did not [9-12]. The age at diagnosis may be important as the highest percentage of complete remission (suspension of insulin therapy) (43\%) was first reported in the study published by Vague in 1987 in patients with a mean age of 23 years [6]. These encouraging results were not confirmed when younger ( $<15$ years of age) patients were treated with NA $[10,11]$. The data from our most recent study suggest that in adult IDDM patients NA can improve metabolic control as much as the combination of NA and cyclosporine [13].

In view of these findings and the relevance that NA may have for IDDM prevention in susceptible children, we decided to conduct a large double-blind trial with NA including children and adults in order to determine whether NA may be given safely to patients with recent-onset IDDM to improve the integrated parameters of metabolic control within the first year of disease.

\section{Subjects, materials and methods}

Selection of patients. Patients with newly-diagnosed IDDM were selected to take part in this study if they fulfilled the following criteria: 1) diagnosis of the disease according to World Health Organisation criteria; 2) age at diagnosis between 5 and 35 years; 3 ) duration of clinical disease less than 4 weeks; 4) no medical contraindications (including pregnancy) or any other major chronic disease; 5) willing and able to participate in regular follow-up. Patients did not suffer from other autoimmune diseases and lived either in Rome or its province. They were followed-up by the staff of the same centre where they were first seen. Each of the seven participating centres contributed nearly equal numbers of patients to the study.

Investigations and follow-up. Patients started on a $55 \%$ carbohydrate diet and received human insulin, short and intermediate acting, three or four times daily. Self-determined capillary glucose was recorded daily; fasting in the morning and twice before and after meals, and insulin dosage was adjusted accordingly to obtain near-normal blood glucose levels.

Patients were examined weekly during the first month of therapy and then monthly by the same team of physicians in each participating centre. Drug toxicity was evaluated at follow-up visits including liver and renal function tests and total blood count. Glycated haemoglobin $\left(\mathrm{HbA}_{1 \mathrm{c}}\right)$ was measured every 3 months by a column assay (BioRad, Milan, Italy), and C-peptide secretion (basal and stimulated with 1 -mg intravenous glucagon) was evaluated after hyperglycaemia was normalized before entry into the trial, and at 3-month intervals for 1 year thereafter. The stimulatory test was always performed with the patient fasting in the morning with blood glucose levels below $10 \mathrm{mmol} / \mathrm{l}$. C-peptide was measured by radio- immunoassay using a commercially available kit (BioRad). The normal range of fasting C-peptide established in 150 healthy subjects aged $5-40$ years is $2-5 \mathrm{ng} / \mathrm{ml}$, with intra- and inter-coefficients of variation of 10 and $15 \%$, respectively. Complete blood count, blood urea nitrogen, serum creatinine, serum electrolytes and bilirubin were monitored every 3 months. As part of the Eurodiab study project [14], IDDM patients diagnosed in our region are HLA typed for DQA and DQB alleles using specific probe oligonucleotides and immune reactivity against islet cells is evaluated by measuring islet cell antibodies and antibodies to glutamic acid decarboxylase.

Treatment protocol. Regular nicotinamide (NA) (IDI Farmaceutici, Pomezia, Italy) was administered at a dose of $25 \mathrm{mg} /$ $\mathrm{kg}$ body weight divided in two doses and administered at meal times. Therapy with NA or placebo was started as soon as informed consent was given, less than 4 weeks from diagnosis.

The study was randomized, double blind and placebo controlled. The protocol was approved by the ethical committee and informed consent was obtained from the patients or their relatives in compliance with local regulations. Patients were stratified according to age and centre of treatment and assigned to treatment according to a computer-generated randomized arrangement. Compliance with treatment was assessed by asking the patient about tablet intake and by counting tablets. Patients were also contacted every month to check on compliance.

Guidelines for insulin therapy. Patients were asked to perform home blood glucose monitoring at least three times daily. Participating centres adopted the same therapeutic protocol consisting of three to four injections per day of regular and lente insulin.

If preprandial blood glucose values were less than $6.5 \mathrm{mmol} / \mathrm{l}$ the insulin dose was decreased by $10 \%$; if blood glucose levels were consistently less than $4.5 \mathrm{mmol} / \mathrm{l}$, the insulin dose was decreased by $20 \%$. Insulin therapy was not discontinued unless 2-h postprandial blood glucose values measured at home were consistently less than $7.5 \mathrm{mmol} / \mathrm{l}$. Patients with blood glucose values above $10 \mathrm{mmol} / \mathrm{l}$ received a $10 \%$ increase in insulin dose or had their insulin regimen modified. Frequent telephone consultations were arranged with patients in order to regulate adjustments to the insulin dose.

Evaluation of response to therapy. This was monitored throughout the study by investigating the integrated measures of metabolic control (insulin dose, $\mathrm{HbA}_{1}$ and C-peptide) at 3month intervals.

Sample size and statistical analysis. The number of patients to be included in the study was calculated based on the analysis of NA trials published in the past in recent-onset IDDM patients on the assumption of improved parameters of metabolic control 1 year after diagnosis in half of the treated patients compared to the control group. Setting alpha (probability of type 1 error) equal 0.05 and beta (probability of a type II error) equal $90 \%$, the required sample size was 50 for a twosided test. Allowing for dropouts, 28 patients were allocated per group to ensure a reasonable sample size.

\section{Statistical analysis}

Statistical analysis was conducted using an IBM computer and SPSS software. For the evaluation of results of the integrated parameters of metabolic control, a repeated measure analysis of variance and Student's $t$-test for independent means were used. 
Table 1. Clinical characteristics of patients at entry in the trial

\begin{tabular}{|c|c|c|c|c|}
\hline & $\begin{array}{l}\text { Nicotinamide } \\
\text { whole group }\end{array}$ & $\begin{array}{l}\text { Over } 15 \text { years } \\
\text { of age }\end{array}$ & $\begin{array}{l}\text { Placebo } \\
\text { whole group }\end{array}$ & $\begin{array}{l}\text { Over } 15 \text { years } \\
\text { of age }\end{array}$ \\
\hline $\begin{array}{l}n \\
\text { (male/female) }\end{array}$ & $\begin{array}{l}28 \\
(16 / 12)\end{array}$ & $\begin{array}{l}6 \\
(4 / 2)\end{array}$ & $\begin{array}{l}28 \\
(16 / 12)\end{array}$ & $\begin{array}{l}7 \\
(6 / 1)\end{array}$ \\
\hline Age (years) & $\begin{array}{l}13.2 \pm 6.7 \\
(5-35)\end{array}$ & $\begin{array}{l}24 \pm 5.7 \\
(18-35)\end{array}$ & $\begin{array}{l}13.2 \pm 6.5 \\
(5-31)\end{array}$ & $\begin{array}{l}22.5 \pm 5.4 \\
(17-31)\end{array}$ \\
\hline $\begin{array}{l}\text { Duration of symptoms before } \\
\text { diagnosis (days) } \\
\text { (range) }\end{array}$ & $\begin{array}{l}29.7 \pm 22.1 \\
(5-90)\end{array}$ & $\begin{array}{l}35.6 \pm 29.9 \\
(7-90)\end{array}$ & $\begin{array}{c}21.6 \pm 27.0 \\
(3-120)\end{array}$ & $\begin{array}{l}20.1 \pm 14.8 \\
(7-45)\end{array}$ \\
\hline $\begin{array}{l}\text { Blood glucose at diagnosis }(\mathrm{mmol} / \mathrm{l}) \\
\text { (range) }\end{array}$ & $\begin{array}{l}18.3 \pm 7.6 \\
(8-42.8)\end{array}$ & $\begin{array}{l}15.5 \pm 4.8 \\
(6-20.8)\end{array}$ & $\begin{array}{l}18.9 \pm 7.2 \\
(7.1-39.7)\end{array}$ & $\begin{array}{l}20.6 \pm 7.1 \\
(11-27.8)\end{array}$ \\
\hline Patients with ketonuria at diagnosis (\%) & 75 & 67 & 85 & 71 \\
\hline $\begin{array}{l}\text { Body mass index }\left(\mathrm{kg} / \mathrm{height}^{2}\right) \\
\text { (range) }\end{array}$ & $\begin{array}{l}19.6 \pm 3.4 \\
(12-26.7) \\
\end{array}$ & $\begin{array}{l}21.2 \pm 2.4 \\
(18-23.9)\end{array}$ & $\begin{array}{l}19.2 \pm 5.0 \\
(13.6-35.6)\end{array}$ & $\begin{array}{l}23.6 \pm 6.5 \\
(13.6-35.6)\end{array}$ \\
\hline $\begin{array}{l}\text { Insulin dose (IU/kg b.w.) } \\
\text { (range) }\end{array}$ & $\begin{array}{l}0.55 \pm 0.3 \\
(0.13-1.17)\end{array}$ & $\begin{array}{l}0.53 \pm 0.22 \\
(0.23-0.86)\end{array}$ & $\begin{array}{l}0.59 \pm 0.5 \\
(0.05-2)\end{array}$ & $\begin{array}{l}0.42 \pm 0.59 \\
(0.07-1.7)\end{array}$ \\
\hline $\begin{array}{l}\mathrm{HbA}_{1 \mathrm{c}}(\%) \\
\text { (range) }\end{array}$ & $\begin{array}{l}8.7 \pm 1.5 \\
(7-13.1)\end{array}$ & $\begin{array}{l}8.13 \pm 0.75 \\
(7.1-8.9)\end{array}$ & $\begin{array}{l}8.9 \pm 1.6 \\
(5.8-14.5)\end{array}$ & $\begin{array}{l}8.9 \pm 2.7 \\
(7.1-10.3)\end{array}$ \\
\hline $\begin{array}{l}\text { Basal C-peptide (ng/ml) } \\
\text { (range) }\end{array}$ & $\begin{array}{l}0.8 \pm 0.7 \\
(0.2-3.3)\end{array}$ & $\begin{array}{l}0.9 \pm 0.6 \\
(0.4-1.7)\end{array}$ & $\begin{array}{l}0.8 \pm 0.8 \\
(0.1-3.7)\end{array}$ & $\begin{array}{l}0.7 \pm 0.3 \\
(0.3-1)\end{array}$ \\
\hline $\begin{array}{l}\text { Stimulated C-peptide (ng/ml) } \\
\text { (range) }\end{array}$ & $\begin{array}{l}1.8 \pm 1.6 \\
(0.3-7.6)\end{array}$ & $\begin{array}{l}1.8 \pm 1.1 \\
(0.9-3.4)\end{array}$ & $\begin{array}{l}1.7 \pm 1.4 \\
(0.1-6.2)\end{array}$ & $\begin{array}{l}1.5 \pm 0.5 \\
(0.9-2.1)\end{array}$ \\
\hline
\end{tabular}

Values are mean \pm SD.

Differences between NA or placebo-treated groups (including patients $>15$ years of age) are not significant for each of the parameters evaluated

Table 2. Insulin dose (IU $/ \mathrm{kg}$ body weight)

\begin{tabular}{llllll}
\hline Patient group & At entry & 3 months & 6 months & 9 months & 12 months \\
\hline Nicotinamide $(n=28)$ & $0.55 \pm 0.31$ & $0.36 \pm 0.26$ & $0.40 \pm 0.28$ & $0.46 \pm 0.33$ & $0.47 \pm 0.33$ \\
Placebo $(n=28)$ & $0.59 \pm 0.46$ & $0.41 \pm 0.25$ & $0.47 \pm 0.28$ & $0.51 \pm 0.36$ & $0.52 \pm 0.31$ \\
\hline
\end{tabular}

Values are mean \pm SD.

$p=\mathrm{NS}$ (analysis of variance)

\section{Results}

The results of this study are shown in Tables $1-4$. The two groups of patients did not differ at the time of diagnosis in respect to their clinical characteristics and the integrated parameters of metabolic control (insulin dose, $\mathrm{HbA}_{1 \mathrm{c}}$, basal and/or stimulated C-peptide)(Table 1). No drop outs were recorded. In both groups after 3 months therapy there was a significant reduction in the insulin dose compared to entry in the trial but the NA and the placebo treated patients did not differ in this respect (Table 2). To obtain optimal metabolic control the insulin dose remained similar in the two groups after 6,9 and 12 months therapy. Over a 1 year observation period, basal C-peptide remained substantially unchanged in NA and placebotreated patients (Table 3 ). No differences were observed in the stimulated C-peptide over the 12month follow-up period.

When age at diagnosis was taken into account, in patients over 15 years of age insulin dose, $\mathrm{HbA}_{1 \mathrm{c}}$ and $\mathrm{C}$-peptide levels were not different at entry between NA and placebo-treated groups and were compar- able to younger patients. However, significant changes in C-peptide secretion were seen over the followup period in patients over 15 years of age. Thus, glucagon stimulated C-peptide levels significantly increased in NA compared to placebo-treated patients $(p<0.02$ analysis of variance) although no significant differences were found at each time point between the two groups (Student's $t$-test) (Table 3 ). In patients under the age of 15 years C-peptide levels (basal and stimulated) did not change in the two groups (data not shown). All patients were metabolically well controlled as shown by the rapid decline in $\mathrm{HbA}_{1 \mathrm{c}}$ levels which remain unchanged thereafter (Table 4).

We then looked at whether HLA and immune status differed amongst older patients and those under 15 years of age, but the small number of the former precluded such an analysis (data not shown). Biochemical parameters including liver and kidney function were normal during follow-up. Finally, no adverse effects were noted in patients receiving either NA or placebo. 
Table 3. C-peptide secretion (whole group)

\begin{tabular}{|c|c|c|c|c|c|}
\hline Patients & At entry & 3 months & 6 months & 9 months & 12 months \\
\hline $\begin{array}{l}\text { Baseline } \\
\text { Nicotinamide }(n=28) \\
\text { Placebo }(n=28)\end{array}$ & $\begin{array}{l}0.8 \pm 0.7 \\
0.8 \pm 0.8\end{array}$ & $\begin{array}{l}1.05 \pm 0.6 \\
1.5 \pm 1.3\end{array}$ & $\begin{array}{l}0.9 \pm 0.7 \\
0.9 \pm 0.9\end{array}$ & $\begin{array}{l}0.8 \pm 0.5 \\
0.7 \pm 0.4\end{array}$ & $\begin{array}{l}0.7 \pm 0.4 \\
0.6 \pm 0.6\end{array}$ \\
\hline $\begin{array}{l}\text { Glucagon stimulated } \\
\text { Nicotinamide }(n=28) \\
\text { Placebo }(n=28)\end{array}$ & $\begin{array}{l}1.8 \pm 1.6 \\
1.7 \pm 1.4\end{array}$ & $\begin{array}{l}1.7 \pm 0.9 \\
2.4 \pm 1.6\end{array}$ & $\begin{array}{l}1.6 \pm 1.1 \\
1.9 \pm 2.0\end{array}$ & $\begin{array}{l}1.4 \pm 0.9 \\
1.1 \pm 0.6\end{array}$ & $\begin{array}{l}1.15 \pm 0.9 \\
1.1 \pm 0.9\end{array}$ \\
\hline $\begin{array}{l}\text { C-peptide secretion in } 1 \\
\text { Baseline } \\
\text { Nicotinamide }(n=6) \\
\text { Placebo }(n=7)\end{array}$ & $\begin{array}{l}\text { over } 15 \text { yea } \\
\begin{array}{l}0.9 \pm 0.6 \\
0.7 \pm 0.3\end{array}\end{array}$ & $\begin{array}{l}0.9 \pm 0.5 \\
0.9 \pm 0.4\end{array}$ & $\begin{array}{l}1.5 \pm 0.9 \\
1.2 \pm 0.5\end{array}$ & $\begin{array}{l}1.1 \pm 0.7 \\
1.0 \pm 0.4\end{array}$ & $\begin{array}{l}1.2 \pm 0.7 \\
1.1 \pm 0.5\end{array}$ \\
\hline $\begin{array}{l}\text { Glucagon stimulated } \\
\text { Nicotinamide }(n=6) \\
\text { Placebo }(n=7)\end{array}$ & $\begin{array}{l}1.8 \pm 1.1 \\
1.5 \pm 0.5\end{array}$ & $\begin{array}{l}1.9 \pm 1.4 \\
1.8 \pm 0.6\end{array}$ & $\begin{array}{l}2.4 \pm 1.0 \\
1.8 \pm 0.8\end{array}$ & $\begin{array}{l}1.8 \pm 1.3 \\
1.5 \pm 0.7\end{array}$ & $\begin{array}{l}1.9 \pm 1.4 \\
1.4 \pm 0.7\end{array}$ \\
\hline
\end{tabular}

Values $(\mathrm{ng} / \mathrm{ml})$ are mean $\pm \mathrm{SD}$.

$p=$ NS (analysis of variance) for both baseline and glucagon stimulated values between the two treated groups (whole group)

$p<0.02$ (analysis of variance) only for glucagon stimulated values between nicotinamide and placebo treated groups (patients over 15 years of age)

Table 4. Glycated haemoglobin $\left(\mathrm{HbA}^{1 \mathrm{l}}\right)$

\begin{tabular}{lllll}
\hline Patients & At entry & 3 months & 6 months & 9 months \\
\hline Nicotinamide $(n=28)$ & $8.7 \pm 1.5$ & $6.6 \pm 1.2$ & $6.6 \pm 1.7$ & $6.7 \pm 1.8$ \\
Placebo $(n=28)$ & $8.9 \pm 1.6$ & $6.5 \pm 2.0$ & $6.4 \pm 1.6$ & $6.9 \pm 1.4$ \\
\hline
\end{tabular}

Values are mean $\% \pm$ SD.

Differences between groups are not significant. Patients in each group show a significant reduction in values at 3 months

compared to entry $(<0.0001)$ which remain unmodified thereafter (analysis of variance)

\section{Discussion}

This is the largest double-blind trial conducted in recent-onset IDDM patients using nicotinamide (NA). We have demonstrated that NA is able to improve stimulated beta-cell function only in patients diagnosed over the age of 15 years.

In previous studies NA showed a beneficial effect mainly in IDDM patients diagnosed after puberty, whereas in younger children NA had no effect on beta-cell function [1]. The patients included in our study have a mean age of 13 years and most are children, therefore our results confirm that in younger recent-onset IDDM patients, when hormonal secretion associated with puberty and insulin resistance can interfere with the achievement of good metabolic control, NA has no effect on beta-cell function. However, in older patients NA can increase transiently stimulated C-peptide secretion and this seems to be consistent also with other reports $[7,8,13]$.

The dose of NA to be employed for therapy also requires particular attention. Thus, the concentration of NA proven to be effective in in vitro studies is approximately 1000 times higher than peak plasma levels in humans. The results of our study suggest that in older patients a dose of $25 \mathrm{mg} / \mathrm{kg} \mathrm{NA}$ is efficacious at least in protecting beta cells from final end destruction. In children either the autoimmune process is more potent or the dose is not sufficient to protect beta cells.

One goal of treatment at IDDM diagnosis is to prolong the period of residual beta-cell function, recognized clinically as the "honeymoon". A reversible, toxic effect on glucose-stimulated beta-cell insulin release induced by hyperglycaemia has been clearly demonstrated in animals and in humans $[15$, 16]. High ambient glucose levels may favour the expression of beta-cell autoantigens, thereby increasing the autoimmune insult leading to beta-cell end stage destruction. It therefore appears that intensive insulin replacement with tight control of hyperglycaemia still remains of paramount importance in newly-diagnosed IDDM patients and should be considered both in terms of hormone replacement as well as specific intervention therapy [17]. Insulin should be administered at maximally tolerated doses and not withdrawn even when a very low dose is required, thus the number of patients in clinical remission or the honeymoon phase (formerly taken as evidence of restoration of beta-cell function) can no longer be used as evidence of an effect. The integrated parameters of metabolic control offer a better way to evaluate efficacy of an adjuvant treatment as proposed by the International Diabetes Immunotherapy Group.

When evaluating the cost/benefit ratio of adjuvant intervention at the time of diagnosis of IDDM, NA should be considered in patients who are diagnosed after puberty. Thus, it has been suggested that in these patients the autoimmune process is slow pro- 
gressing and consequently disease presentation is milder compared with that in young children [18, 19]. Due to the small group of patients over 15 years of age in this study, we cannot confirm this finding, but nevertheless it may suggest why NA by virtue of its protective effects on the beta cell can be efficacious in preserving $C$-peptide secretion in older patients. The early addition of NA to insulin therapy should also be taken into account in view of the possible long-term benefit to the patient in relation to the development of long-term diabetic complications. First of all in clinical terms, it is easier to manage the patient with residual beta-cell function which may be helpful in blunting hyperglycaemic peaks. Furthermore, it should be mentioned that a reduced incidence of microvascular complications has been described in patients with some residual beta-cell function [20]. Finally, it is also worth reiterating that no adverse effects have been encountered with the use of NA and this is particularly encouraging for trials currently on-going with NA in subjects genetically and immunologically susceptible to IDDM with the aim of preventing the disease [21].

In conclusion, evidence to date points to the safety and efficacy of NA as an adjunct to insulin in the early phase of IDDM to protect and improve residual Cpeptide secretion but only in patients who are diagnosed after puberty. However, further studies are required to find out whether NA can maintain its effect on beta-cell secretion in the long run. Moreover, there is still the need to see if any protective effect on the occurrence of long-term diabetic complications may be obtained since NA is expected to improve the integrated parameters of metabolic control.

Acknowledgements. The IMDIAB Study Group wishes to thank the staff members and the nurses of participating centres who have contributed to this trial. This work was in part supported by grants from the "Ministero dell'Università, della Ricerca Scientifica e Tecnologica" Italy and by the "Centro Internazionale Studi Diabete" Rome. The technical assistance of Ms. L. Valente is greatly acknowledged. We are also indebted to Ms. E. Robertson for her skilful assistance in organizing contact and exchange of data between centres. Nicotinamide and placebo were kindly donated by IDI (Pomezia, Rome, Italy).

\section{References}

1. Pozzilli P, Andreani D (1993) Nicotinamide, a vitamin with a potential to prevent type 1 diabetes. Diab Metab Rev 9: 219-239

2. Pociot F, Reimers JI, Andersen HU (1993) Nicotinamide biological actions and therapeutic potential in diabetes prevention. Diabetologia 36: 574-576

3. Kallman B, Burkart U, Krancke KD, Koib-Bachofen V, Kolb H (1992) Toxicity of chemical-generated nitric oxide towards pancreatic islet cells can be prevented by nicotinamide. Life Sci 51: 671-678
4. Buscema M, Vinci C, Gatta C, Rabuazzo AM, Vigneri R, Purrello F (1992) Nicotinamide partially reverses the interleukin-1beta inhibition of glucose induced insulin release in pancreatic islets. Metabolism 41: 296-300

5. Varsnyi-Nagy M, Dadufalza V, Buckingham B et al (1992) Protective effect of nicotinamide on preservation of mouse islet function and morphology. Diabetologia 35 [Suppl]: A129 (Abstract)

6. Vague PH, Vialettes B, Lassman-Vague V, Vallo JJ (1987) Nicotinamide may extend remission phase in insulin dependent diabetes. Lancet I:619-620 (Letter)

7. Pozzilli P, Visalli N, Ghirlanda G, Manna R, Andreani D (1989) Nicotinamide increases C-peptide secretion in patients with recent onset type 1 diabetes. Diabet Med 6: 568-572

8. Vague P, Picq R, Bernal M, Lassman-Vague V, Vialettes B (1989) Effect of nicotinamide treatment in the residual insulin secretion in type 1 (insulin-dependent) diabetic patients. Diabetologia 32: 316-321

9. Mendola G, Casamitjana R, Gomics R (1989) Effect of nicotinamide therapy upon B-cell function in newly diagnosed type 1 (insulin-dependent) diabetic patients. Diabetologia 32: 160-162

10. Chase HP, Butler-Simon N, Garg S, McDuffe M, Hoops SL, O'Brien D (1990) Trial of nicotinamide in newly diagnosed patients with type 1 (insulin-dependent) diabetes mellitus. Diabetologia 33: 444-446

11. Lewis CM, Canafax DM, Sprafka JM, Barbosa JJ (1992) Double blind randomized trial of nicotinamide on early onset diabetes. Diabetes Care 15: 121-123

12. Vialettes B, Picq R, Du Rostu M et al. (1991) A preliminary multicentre study of the treatment of recently diagnosed type 1 diabetes by combination nicotinamide-cyclosporin therapy. Diabet Med 7: 731-735

13. Pozzilli P, Visalli N, Boccuni ML, et al. (1994) Randomized trial comparing nicotinamide plus cyclosporin in recent onset insulin dependent diabetes. Diabet Med 11: 98 104

14. Buzzetti R, Nisticò L, Osborn JF et al. (1993) HLA-DQA1 and DQB1 gene polymorphisms in type 1 (insulin dependent) diabetic patients from central Italy and their use for risk prediction. Diabetes 42: 1173-1178

15. Rossetti L, Giaccari A, DeFronzo RA (1990) Glucose toxicity. Diabetes Care 13: 610-630

16. Leahy JL, Bonner-Weir S, Weir GC (1992) Beta cell dysfunction induced by chronic hyperglycemia. Current ideas on mechanism of impaired glucose-induced secretion. Diabetes Care 15: 442-455

17. Muir A, Schatz DA, Pozzilli P, Maclaren NK (1993) Intervention therapies for insulin-dependent diabetes. Autoimmunity $16: 301-310$

18. Pozzilli P, Andreani D (1990) Type 1 diabetes at presentation of juvenile diabetes. BMJ ii:211-212

19. Pinkney JH, Bingley PJ, Sawtell PA, Dunger DB, Gale EAM, The Bart's-Oxford Study Group (1994) Presentation and progress of childhood diabetes mellitus: a prospective population-based study. Diabetologia 37: 70-74

20. Sjöberg S, Gunnarsson R, Gjotterberg M, Lefvert AK, Persson A, Östman J (1987) Residual insulin-production glycaemic control and prevalence of microvascular lesions and polyneuropathy in long-term type 1 (insulin-dependent) diabetes mellitus. Diabetologia 30: 208-211

21. Chase P, Dupre J, Mahon J et al. (1992) Nicotinamide and prevention of diabetes. Lancet 339: 1051-1052 